\title{
Hydrography and circulation west of Sardinia in June 2014
}

\author{
Michaela Knoll $^{1}$, Ines Borrione ${ }^{2}$, Heinz-Volker Fiekas ${ }^{1}$, Andreas Funk ${ }^{1}$, Michael P. Hemming ${ }^{3,4}$, Jan Kaiser ${ }^{3}$, \\ Reiner Onken ${ }^{5}$, Bastien Queste ${ }^{3}$, and Aniello Russo ${ }^{2}$ \\ ${ }^{1}$ Wehrtechnische Dienststelle für Schiffe und Marinewaffen, Maritime Technologie und Forschung (WTD71), \\ Berliner Straße 115, 24340 Eckernförde, Germany \\ ${ }^{2}$ NATO Science and Technology Organization, Centre for Maritime Research and Experimentation (CMRE), \\ Viale San Bartolomeo 400, 19126 La Spezia, Italy \\ ${ }^{3}$ Centre for Ocean and Atmospheric Sciences (COAS), School of Environmental Sciences, University of East Anglia \\ (UEA), Norwich Research Park, Norwich, NR4 7TJ, UK \\ ${ }^{4}$ Laboratoire d'Océanographie et du Climat, 4 Place Jussieu, 75005 Paris, France \\ ${ }^{5}$ Helmholtz-Zentrum Geesthacht, Centre for Materials and Coastal Research (HZG), Max-Planck-Straße 1, \\ 21502 Geesthacht, Germany
}

Correspondence to: Michaela Knoll (michaelaknoll@bundeswehr.org)

Received: 23 May 2017 - Discussion started: 6 June 2017

Revised: 18 August 2017 - Accepted: 21 August 2017 - Published: 13 November 2017

\begin{abstract}
In the frame of the REP14-MED sea trial in June 2014 , the hydrography and circulation west of Sardinia, observed by means of gliders, shipborne CTD (conductivity, temperature, depth) instruments, towed devices, and vesselmounted ADCPs (acoustic doppler current profilers), are presented and compared with previous knowledge. So far, the circulation is not well-known in this area, and the hydrography is subject to long-term changes. Potential temperature, salinity, and potential density ranges as well as core values of the observed water masses were determined. Modified Atlantic Water (MAW), with potential density anomalies below $28.72 \mathrm{~kg} \mathrm{~m}^{-3}$, showed a salinity minimum of 37.93 at 50 dbar. Levantine Intermediate Water (LIW), with a salinity maximum of about 38.70 at $400 \mathrm{dbar}$, was observed within a range of $28.72<\sigma_{\Theta} /\left(\mathrm{kg} \mathrm{m}^{-3}\right)<29.10$. MAW and LIW showed slightly higher salinities than previous investigations. During the trial, LIW covered the whole area from the Sardinian shelf to $7^{\circ} 15^{\prime} \mathrm{E}$. Only north of $40^{\circ} \mathrm{N}$ was it tied to the continental slope. Within the MAW, a cold and saline anticyclonic eddy was observed in the southern trial area. The strongest variability in temperature and salinity appeared around this eddy, and in the southwestern part of the domain, where unusually low saline surface water entered the area towards the end of the experiment. An anticyclonic eddy of Winter Intermediate Water was recorded moving northward at $0.014 \mathrm{~m} \mathrm{~s}^{-1}$. Geostrophic currents and water mass
\end{abstract}

transports calculated across zonal and meridional transects showed a good agreement with vessel-mounted ADCP measurements. Within the MAW, northward currents were observed over the shelf and offshore, while a southward transport of about $1.5 \mathrm{~Sv}$ occurred over the slope. A net northward transport of $0.38 \mathrm{~Sv}$ across the southern transect decreased to zero in the north. Within the LIW, northward transports of $0.6 \mathrm{~Sv}$ across the southern transects were mainly observed offshore, and decreased to $0.3 \mathrm{~Sv}$ in the north where they were primarily located over the slope. This presentation of the REP14-MED observations helps to further understand the long-term evolution of hydrography and circulation in the Western Mediterranean, where considerable changes occurred after the Eastern Mediterranean Transient and the Western Mediterranean Transition.

\section{Introduction}

From 6 to 25 June 2014, an extensive experiment called REP14-MED was carried out west of Sardinia in the area between $39^{\circ} 12^{\prime} \mathrm{N}$ and $40^{\circ} 12^{\prime} \mathrm{N}$ and between $7^{\circ} 15^{\prime} \mathrm{E}$ and $8^{\circ} 18^{\prime} \mathrm{E}$ (Onken et al., 2017). In this paper, all dates refer to the year 2014 unless otherwise stated. The two research vessels Alliance and Planet, and a variety of measuring platforms, were used to capture the hydrography and circula- 
Table 1. Abbreviations of water masses, features, and areas used in this study. The acronyms mainly correspond to the recommendations of the round table session on Mediterranean Water Mass Acronyms at the 36th CIESM (Commission Internationale pour l'Exploration Scientifique de la mer Méditerranée) Congress in Monte Carlo in September 2001 (http://ciesm.org/ events/RT5-WaterMassAcronyms.pdf).

\begin{tabular}{ll}
\hline Acronym & Water mass, feature or area \\
\hline AE & Algerian Eddy \\
AW & Atlantic Water \\
BW & Bottom Water \\
EMT & Eastern Mediterranean Transient \\
LIW & Levantine Intermediate Water \\
MAW & Modified Atlantic Water \\
SE & Sardinian Eddy \\
TML & Temperature Minimum Layer \\
WIW & Winter Intermediate Water \\
WMDW & Western Mediterranean Deep Water \\
WMED & Western Mediterranean \\
WMT & Western Mediterranean Transition \\
WSC & Western Sardinian Current \\
\hline
\end{tabular}

tion in the area. One of the objectives was to collect data for operational ocean forecasting, model validation, and the evaluation of forecasting skill. Other aims were to explore the variability of the ocean and to study mesoscale and submesoscale features. For those investigations, a detailed analysis of the recorded measurements is necessary. Therefore, the aim of this study is to provide an overview of the hydrography and circulation west of Sardinia observed during REP14-MED. Within the trial period of 18 days, measurements were made at the same position on several occasions. This enabled a study of short-term variations in the upper water column, The REP14-MED observations were compared with previous knowledge to investigate long-term changes.

The hydrography of the Sardinian Sea, which is located between 38 and $42^{\circ} \mathrm{N}$ and between $7^{\circ} \mathrm{E}$ and the Sardinian coast (Ribotti et al., 2004), is characterized by various water masses: Modified Atlantic Water (MAW; see Table 1 for list of acronyms), Winter Intermediate Water (WIW), Temperature Minimum Lyer (TML), Levantine Intermediate Water (LIW), Western Mediterranean Deep Water (WMDW), and Bottom Water (BW). Atlantic Water (AW) entering the Western Mediterranean (WMED) at the surface through the Strait of Gibraltar is intensively mixed and modified on its way towards the east. This water mass, referred to as MAW, covers approximately the upper $150 \mathrm{~m}$ of the WMED with a salinity range of 36.5 to 38.0 in the Algerian Basin (Benzohra and Millot, 1995) and 37.2 to 38.2 in the Sardinian Sea (Sorgente et al., 2003). The core of MAW is characterized by a minimum in salinity found during summer at about 50-70 $\mathrm{m}$ depth and during winter close to the surface ( $\mathrm{La}$ Violette, 1994). Based on historical data, the mean potential temperature and salinity of the core in summer in the Sardinian Sea are $17.71^{\circ} \mathrm{C}$ and 37.61 with a standard deviation of $2.87^{\circ} \mathrm{C}$ and 0.33 , respectively (Sparnocchia et al., 1994). WIW consists of cooled and homogenized MAW formed in winter during cold wind events in the northern WMED (Juza et al., 2013). It is characterized by local minima in potential temperature and salinity at about 150 to $200 \mathrm{~m}$ depth, with magnitudes depending on the formation conditions. Values of $12.35^{\circ} \mathrm{C}$ and 38.3 are observed in the zone of formation (Benzohra and Millot, 1995; Vargas-Yáñez et al., 2012). WIW mainly follows the path of MAW westward along the European continental slope and across the Algerian Basin (Millot, 1999; Benzohra and Millot, 1995). An additional pathway of WIW directly connecting the formation area to the Algerian Basin is expected to be induced by frontal eddies associated with the North Balearic Front (Millot, 1999; Fuda et al., 2000). This North Balearic Front separates the Atlantic Water reservoir in the south from the saltier and denser waters in the north (Olita et al., 2013). The TML is observed in the Alboran Sea (Allen et al., 2008), the Algerian Basin (Benzohra and Millot, 1995), and the Sardinian Sea (Sorgente et al., 2003). It is not an autonomous water mass, but consists of WIW modified continually on its way through the WMED. Potential temperature and salinity values are below $13.2^{\circ} \mathrm{C}$ and 38.3 , respectively. LIW is formed in the eastern Mediterranean, entering the WMED through the Strait of Sicily. It is characterized by high salinities with core values of about 38.7 (Juza et al., 2013, 2015; Bosse et al., 2015). In the Sardinian Sea, the mean core values of potential temperature and salinity during summer based on historical data are $13.51^{\circ} \mathrm{C}$ and 38.58 with a standard deviation of $0.20^{\circ} \mathrm{C}$ and 0.06 , respectively (Sparnocchia et al., 1994). WMDW is formed in winter by deep convection of mixed MAW and LIW in the northwestern corner of the WMED, mainly in the Gulf of Lions, with potential temperatures and salinities of 12.8 to $12.9^{\circ} \mathrm{C}$ and 38.4 to 38.5 , respectively. WMDW spreads through the WMED and occupies the water column below 800 m (La Violette, 1994; Schott et al., 1996; Rixen et al., 2005; Bosse et al., 2015).

In recent decades, water masses in the Mediterranean Sea have been subject to considerable change. The Eastern Mediterranean Transient (EMT) caused a significant increase in the heat and salt content of the LIW (Roether et al., 2007, 2014). This increase in temperature and salinity has reached the western basins and has affected, amongst others, the characteristics of WMDW. Below $200 \mathrm{dbar}$, the mean temperature and salinity in the WMED have risen by about $0.04^{\circ} \mathrm{C}$ and 0.015 , respectively, per decade since 1961 , with increases in LIW twice as large as in the deep water (Borghini et al., 2014). Since the 1950s, the heat and salt content of BW have increased steadily. This increase has heavily intensified since 1985 (Rixen et al., 2005; Krahmann and Schott, 1998). A major deep water formation event in winter 2004/2005 started the Western Mediterranean Transition (WMT) (Schroeder et al., 2016). Within two years, BW ex- 
perienced an increase in potential temperature and salinity of $0.038^{\circ} \mathrm{C}$ and 0.016 , respectively (Schroeder et al., 2008). One reason for the changes in the deep water is the transfer of the EMT signal to the WMED, with higher heat and salt content of the advected LIW which is part of the WMDW formation.

The circulation in the Sardinian Sea is scarcely known from previous investigations. The upper $300 \mathrm{~m}$ of the water column is dominated by meso- $(10-100 \mathrm{~km})$ to submesoscale $(<10 \mathrm{~km})$ features, predominantly anticyclonic eddies of different origin (Puillat et al., 2003; Ribotti et al., 2004). Large Algerian Eddies (AE), with a diameter of 50 to $250 \mathrm{~km}$, are generated in the Algerian Basin by baroclinic instabilities of the Algerian Current, which flows eastward along the African coast. These AEs embed less saline water of Atlantic origin and circulate cyclonically within a gyre around the Algerian Basin with a mean speed of a few centimetres per second. They have lifetimes of up to 3 years (Puillat et al., 2002), often extending from the surface to about $350 \mathrm{~m}$ or deeper, and bring relatively fresh MAW from the Algerian coast to the Sardinian Sea (Millot, 1999; Testor and Gascard, 2005; Olita et al., 2013). Several AEs were observed in the Sardinian Sea between $7^{\circ} 24^{\prime} \mathrm{E}$ and $8^{\circ} \mathrm{E}$ during the MedGOOS experiments in 2001 and 2002 (Ribotti et al., 2004; Puillat et al., 2006). Results of ocean general circulation models show that these eddies feed the Western Sardinian Current (WSC), a quasi-permanent southward flow at the surface west of Sardinia (Olita et al., 2013, 2015; Pinardi et al., 2015). At the southwest corner of Sardinia, the WSC is located closer to the coast and reaches its maximum intensity. Coastal upwelling, especially evident in the southwestern part of Sardinia, is preconditioned by the WSC (Olita et al., 2013).

According to Ekman theory, northerly winds induce favourable conditions for upwelling along the western Sardinian coast. This could be observed during MedGOOS 3 in September 2001, where wind speeds between 4 and $12 \mathrm{~m} \mathrm{~s}^{-1}$ were recorded (Ribotti et al., 2004). At that time, a vertical salinity inversion occurred at about 30 to $50 \mathrm{~m}$ depth in the whole sampling field. Therefore, upwelling, which mainly took place north of $40^{\circ} \mathrm{N}$, was leading to lower salinities close to the shore. This salinity inversion may have been generated by evaporation or by saline water from the shelf pushed by the wind-induced Ekman transport further offshore. Water on the shelf can be significantly more saline than further offshore where AEs bring fresher water from the south (Ribotti et al., 2004).

The LIW spreads into the WMED between 200 and $800 \mathrm{~m}$ of depth (La Violette, 1994). South of Sardinia, the LIW vein flowing westward is about $50 \mathrm{~km}$ wide, with a core at about $400 \mathrm{~m}$ (Bouzinac et al., 1999). At the southwest corner of Sardinia, it turns northward and follows the continental slope (Sorgente et al., 2003). The LIW vein becomes wider, shallower, and cooler (Millot, 1999). It continues northward west of Corsica and turns to the west, flowing as a coastal current along the European slope, where it takes part in the formation of WMDW. At the southwest corner of Sardinia, the LIW sporadically spreads westward. Instead of a permanent flow branch, it is due to patches or filaments of LIW induced by AEs (Puillat et al., 2006; Millot and Taupier-Letage, 2005) or due to the formation of barotropic Sardinian Eddies (SEs) with LIW characteristics (Testor and Gascard, 2005; Bosse et al., 2015). The SEs stay south of the North Balearic Front and are often entrained southward by the Algerian Gyre. SEs are formed at intermediate depths, but usually show a surface signature after some weeks (Olita et al., 2013). The westward transport of LIW into the WMED is estimated to be roughly $1 \mathrm{~Sv}$ (Millot, 1999), while the eastward transport of MAW at the Sardinian Channel is nearly $2 \mathrm{~Sv}$. A rough estimation of the total northward transport between Sardinia and Mallorca (Spain) based on water and salt budgets yielded about $0.4 \mathrm{~Sv}$ (Bethoux, 1980).

This paper is organized into six sections. Since several instruments were involved in this study, a comparison is carried out in Sect. 2 to distinguish between variations due to instrumental bias and due to environmental features. The characteristics of the different water masses recorded in the trial area are specified in Sect. 3. These are compared with previous investigations and potential temporal changes are discussed. The vertical and horizontal distributions of the water masses are indicated and special features like eddies and fronts are presented. Based on the CTD (conductivity, temperature, depth) profiles taken at the same position on several occasions within the measuring period of 18 days, short-term variations in the upper water column are discussed in Sect. 4. Direct current observations obtained with vessel-mounted ADCPs (acoustic doppler current profiler) are presented in Sect. 5 and compared with geostrophic velocities and transports calculated within the MAW and the LIW based on the CTD transects covering the area between the Sardinian coast and the deep ocean at $7^{\circ} 15^{\prime} \mathrm{E}$. Finally, the paper's findings are summarized in Sect. 6.

\section{Data set and sensor comparison}

For this paper, temperature and salinity measurements were utilized from the following instruments: Sea-Bird CTDs from Alliance and Planet, an Oceanscience Underway CTD (UCTD), a towed CTD chain, a towed ScanFish, three Seagliders named Fin (SG537), Kong (SG524), and Minke (SG510), and six Slocum gliders called Elettra, Noa, Jade, Zoe, Dora, and WTD71. The CTD data were mainly obtained along 11 zonal transects, partly repeated several times and spaced by $6 \mathrm{nmi}$ (nautical miles) or about $11 \mathrm{~km}$ from each other. Further zonal transects situated in between were surveyed several times back and forth by the gliders (Fig. 1).

A comparison between the different CTD instruments was carried out to ensure that observed differences were based on actual environmental variability. In the deep ocean, where 


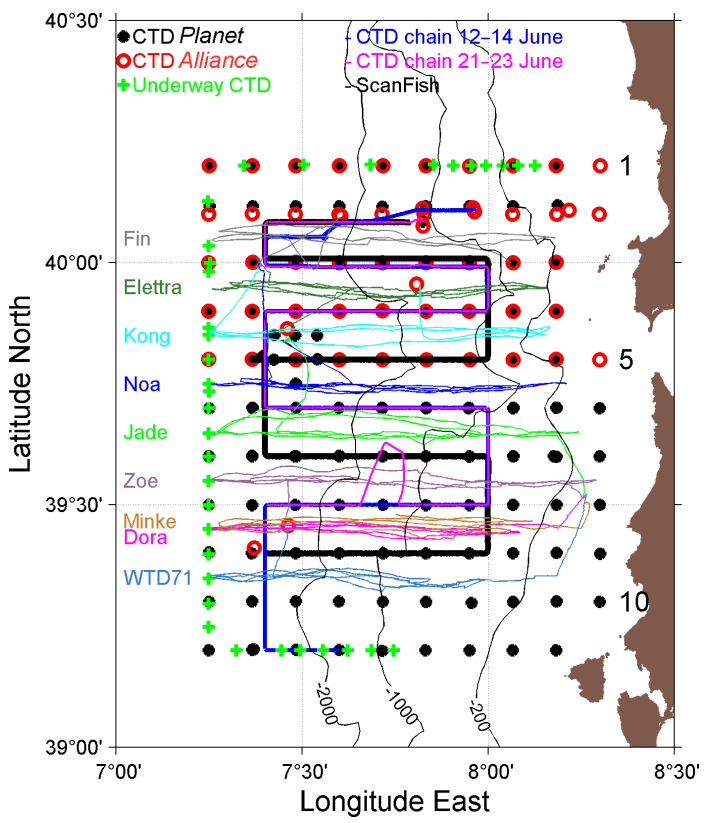

Figure 1. CTD data sets obtained with different instruments. Glider names are specified next to their tracks. For reference, zonal CTD transects 1, 5, and 10 are also marked. Thin black lines denote the 200,1000 , and $2000 \mathrm{~m}$ isobaths.

the natural variability of potential density anomaly $\left(\sigma_{\Theta}\right)$ was low, a systematic difference of $0.008 \mathrm{~kg} \mathrm{~m}^{-3}$ was observed between the CTD sensors of Planet and Alliance (Fig. 2), which was slightly above the expected accuracy of about $0.004 \mathrm{~kg} \mathrm{~m}^{-3}$. Systematic differences in $\sigma_{\Theta}$ in the deep ocean were also observed between the shipborne CTDs and some of the deep profiling gliders. Compared to the Planet CTD measurements, gliders Noa, Jade, and Minke recorded slightly lower $\sigma_{\Theta}$, while glider Fin observed slightly higher $\sigma_{\Theta}$ values (Fig. 3). No significant difference was observed between the Planet measurements and glider Kong. Glider Dora exhibited high variations in $\sigma_{\Theta}$ at about $900 \mathrm{dbar}$, whereas all other CTD instruments showed almost constant zonal values. Since measurements by Planet covered all latitudes of the trial area, the shifts cannot simply be explained by latitudinal changes. The differences in $\sigma_{\Theta}$ between the sensors of the shipborne CTDs and the gliders were small, but mostly constant. In contrast to $\sigma_{\Theta}$, variations in potential temperature and salinity at a pressure of $900 \mathrm{dbar}$ were much higher, with values rising towards the east (Fig. 3). Due to the variability in potential temperature and salinity, the differences between $\sigma_{\Theta}$ values of the different instruments cannot be ascribed to a specific sensor. Only the discrepancy between the Sea-Bird CTDs of both ships could be explained by differences in conductivity due to the existence of profiles below 2000 dbar (Knoll et al., 2015a). Data of the ARGO float 6901836, obtained in the trial area in June, agreed well with $\sigma_{\Theta}$ values obtained in the deep ocean by Alliance. Further casts were recorded using an UCTD at the outer limits of the
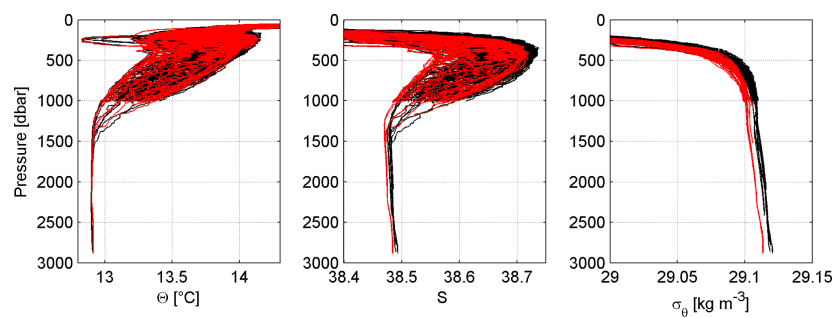

Figure 2. Potential temperature $(\Theta)$, salinity $(S)$, and potential density anomaly $\left(\sigma_{\Theta}\right)$ profiles of Sea-Bird CTD casts obtained by Planet (black) and Alliance (red) with a focus on the lower water column.
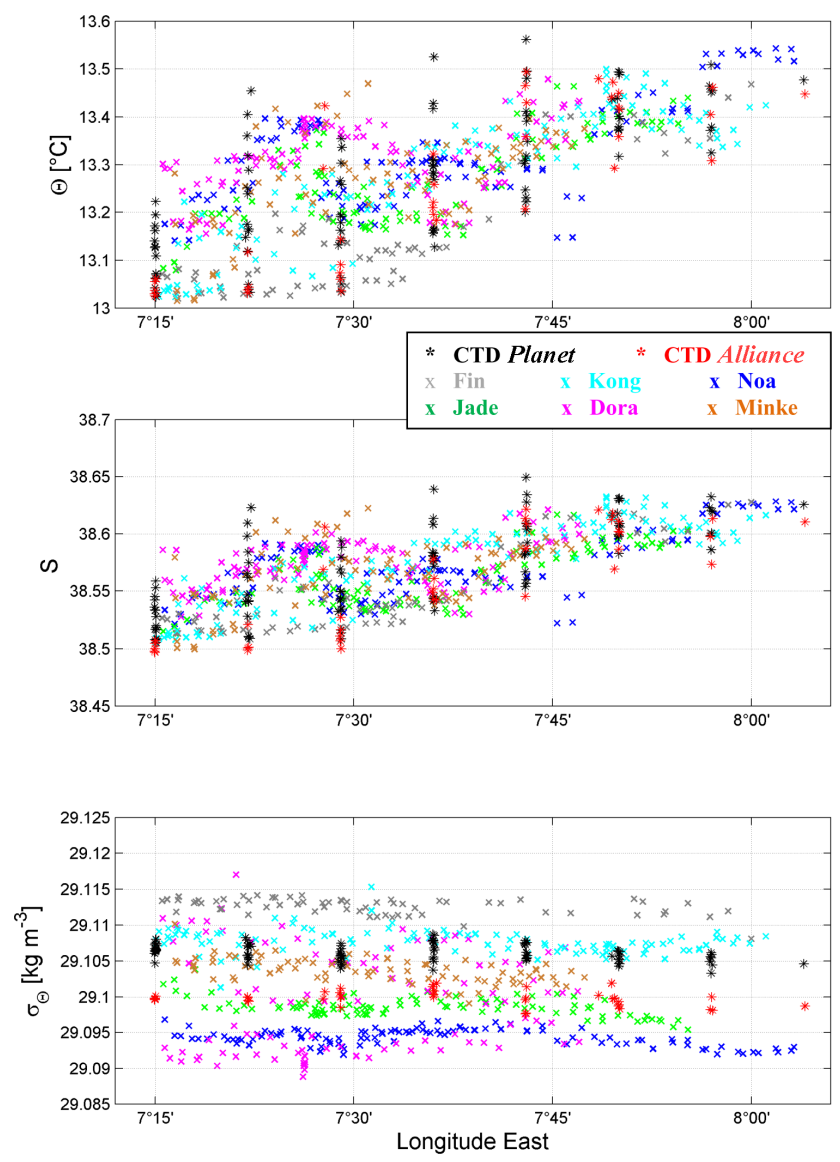

Figure 3. Potential temperature $(\Theta)$, salinity $(S)$, and potential density anomaly $\left(\sigma_{\Theta}\right)$ at roughly $900 \mathrm{dbar}$ versus longitude of all CTD and glider profiles available at that pressure level. Planet covered all latitudes of the trial area, Alliance observed in the northern part, and the gliders surveyed at selected latitudes given in Fig. 1.

trial area (Fig. 1). The $\sigma_{\Theta}$ values below $400 \mathrm{dbar}$ were often about $0.015 \mathrm{~kg} \mathrm{~m}^{-3}$ lower than the ones observed in nearby CTD casts of Planet. However, due to the temperature and salinity accuracy of the UCTD of about $0.005^{\circ} \mathrm{C}$ and 0.05 , respectively, the observed difference in $\sigma_{\Theta}$ was not significant. 
In the upper water column, the range of natural variations was too large to detect small differences between the different sensors. The measurements of the shallow gliders Elettra, Zoe, and WTD71 were within the range of the CTD observations obtained by both ships. The same is true for the measurements obtained in the upper $200 \mathrm{~m}$ of the water column by the towed CTD chain and the ScanFish. Before towing, in situ calibration coefficients of the CTD chain sensors were determined based on simultaneously recorded CTD casts of Planet. Thus, no systematic discrepancy existed between the CTD chain and the Sea-Bird CTD of Planet. The accuracies of the CTD chain temperature and salinity measurements were about $0.02{ }^{\circ} \mathrm{C}$ and 0.05 , respectively. A comparison between the CTD chain and the ScanFish towed in sync showed no significant differences. Concerning investigations of temperature and salinity variability in the upper water column, the differences between the platforms were negligible when compared with natural variations. However, for studying changes in $\sigma_{\Theta}$ at greater depths, the differences between the different sensors have to be taken into account.

\section{Water masses}

The characteristics of the different water masses, observed by means of all CTD instruments and gliders used during REP14-MED, are specified below distinguishing between ranges and core values of the different parameters (Fig. 4 and Table 2). The observations are compared with earlier results. The indicated salinity and potential density anomaly values given in Table 2 correspond to the CTD observations of Planet. According to the sensor comparison results, these values exhibit uncertainties in conductivity and potential density of about $0.001 \mathrm{~S} \mathrm{~m}^{-1}$ and $0.01 \mathrm{~kg} \mathrm{~m}^{-3}$, respectively. Also, spatial changes in the water mass characteristics are presented by means of selected zonal transects of potential temperature, salinity, and potential density anomaly (Fig. 5) as well as horizontal distributions of various parameters at different depth or density levels (Figs. 6, 7, 8, and 9).

\subsection{MAW}

The salinity range of MAW observed during REP14-MED was slightly higher than the older measurements of Sparnocchia et al. (1994), and Benzohra and Millot (1995) (Table 2). The salinity and $\sigma_{\Theta}$ values increased towards the shelf (Fig. 5). A local salinity minimum occurred at about $50 \mathrm{dbar}$ with mean values of 37.93, somewhat higher, and with about $15.19^{\circ} \mathrm{C}$, considerably colder than the mean historical values observed by Sparnocchia et al. (1994). In order to understand how salinity within the core of the MAW changed with longitude, values and pressure levels of the salinity minima identified in all CTD profiles collected from Planet and Alliance are shown in Fig. 6 panels a and b, with sampling
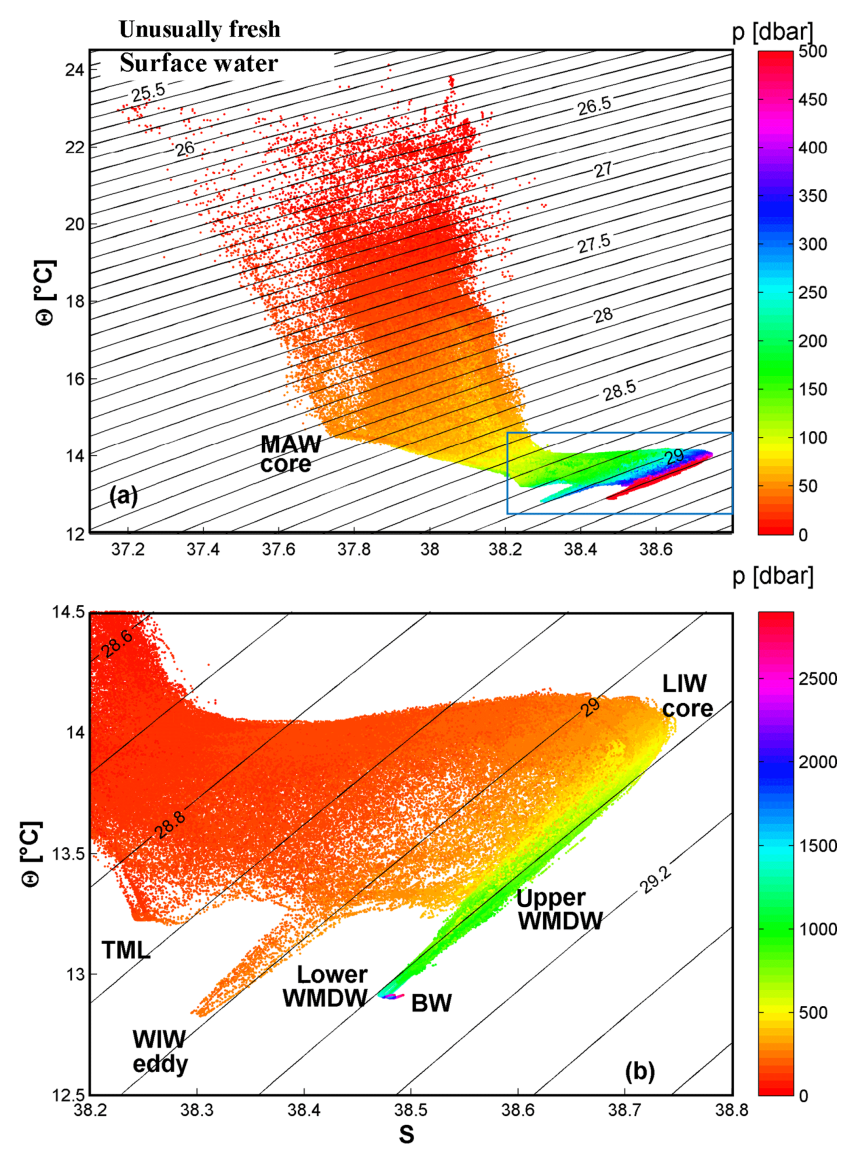

Figure 4. Potential temperature vs. salinity $(\Theta$ vs. $S$ ) diagram with contours of potential density anomaly $\left(\sigma_{\Theta}\right)$ (black) of all CTD casts and gliders. Diagrams are presented for the (a) whole water column with coloured pressure in the upper $500 \mathrm{dbar}$ and coloured red below (blue box indicates the range shown in Fig. 6b), and (b) lower water column with coloured pressure between 0 and $2900 \mathrm{dbar}$.

locations marked in Fig. 1. Close to the coast, the salinity minima within pressure values of 40 and 80 dbar increased to greater than 38 .

The core of the MAW with the salinity minimum was located at about $\sigma_{\Theta}=28.19 \mathrm{~kg} \mathrm{~m}^{-3}$ (Fig. 4a). The lower boundary was defined at the $\sigma_{\Theta}=28.72 \mathrm{~kg} \mathrm{~m}^{-3}$ isopycnal, which corresponded to a pressure level of 80 to $140 \mathrm{dbar}$ (Fig. 6c). Below this isopycnal, the salinity strongly increased as a result of LIW. Furthermore, TML and WIW were observed at depths below this density level.

Towards the end of the experiment, unusually low salinities of less than 37.2 occurred at the surface in the southwestern part of the trial area (Fig. 6d). This feature did not appear in the earlier CTD measurements of Planet obtained in the same area at the beginning of the experiment. Similar salinity values of less than 37.2 were observed in AEs in the eastern part of the Algerian Basin (Benzohra and Millot, 1995; Taupier-Letage et al., 2003), and they also occurred in 
Table 2. Ranges and core characteristics of the parameters pressure, potential density anomaly $\left(\sigma_{\Theta}\right)$, potential temperature $(\Theta)$, and salinity $(S)$ of water masses in the WMED obtained from literature and the REP14-MED data set. Specifications in brackets refer to core values. Italic indications correspond to TML characteristics.

\begin{tabular}{|c|c|c|c|c|c|}
\hline $\begin{array}{l}\text { Water mass } \\
\text { characteristic } \\
\text { origin }\end{array}$ & $\begin{array}{l}\text { Pressure range } \\
\text { (core) } \\
(\text { dbar })\end{array}$ & $\begin{array}{l}\sigma_{\Theta} \text { range } \\
(\text { core }) \\
\left(\mathrm{kg} \mathrm{m}^{-3}\right)\end{array}$ & $\begin{array}{l}\Theta \text { range } \\
\text { (core) } \\
\left({ }^{\circ} \mathrm{C}\right)\end{array}$ & $\begin{array}{l}S \text { range } \\
\text { (core) }\end{array}$ & $\begin{array}{l}\text { Reference study } \\
\text { where values are measured } \\
\text { or just mentioned }\end{array}$ \\
\hline MAW & $\begin{array}{l}0-140 \\
(50)\end{array}$ & $\begin{array}{l}<28.72 \\
(28.19)\end{array}$ & $\begin{array}{l}13.6-24.2 \\
(15.19)\end{array}$ & $\begin{array}{l}37.15-38.3 \\
(37.93)\end{array}$ & REP14-MED data \\
\hline low-salt & & & $\begin{array}{l}\text { (summer } \\
17.71)\end{array}$ & $\begin{array}{l}\text { (summer } \\
37.61 \text { ) }\end{array}$ & Sparnocchia et al. (1994) \\
\hline \multirow[t]{3}{*}{ Strait of Gibraltar } & $\begin{array}{l}0-200 \\
\text { (summer: 50-70) }\end{array}$ & & & $36.5-37.5$ & La Violette (1994) \\
\hline & $0-150$ & & $13.5-23$ & $36.5-38.0$ & Benzohra and Millot (1995) \\
\hline & $0-150$ & & $13.7-15.2$ & $37.2-38.2$ & Sorgente et al. (2003) \\
\hline $\begin{array}{l}\text { WIW/ } \\
T M L \\
\text { cold, low-salt/ }\end{array}$ & $\begin{array}{l}170-400 \\
(250) \\
120-270 \\
(200)\end{array}$ & $\begin{array}{l}(28.99) \\
(28.86-28.89)\end{array}$ & $\begin{array}{l}(<12.9) \\
(<13.25)\end{array}$ & $\begin{array}{l}(<38.3) \\
(38.24-38.30)\end{array}$ & REP14-MED data \\
\hline cold layer, & $(150-200)$ & & $\begin{array}{l}(12.35) \\
(12.65-13.2)\end{array}$ & $\begin{array}{l}(38.3) \\
(38.3)\end{array}$ & Benzohra and Millot (1995) \\
\hline northern WMED & $150-250$ & & $13.3-13.5$ & & Sorgente et al. (2003) \\
\hline \multirow[t]{3}{*}{$\begin{array}{l}\text { not formed every year / } \\
\text { modified WIW }\end{array}$} & $\begin{array}{l}200->360 \\
(<300)\end{array}$ & & $\begin{array}{l}(12.9) \\
(<13.5)\end{array}$ & $\begin{array}{l}(38.20) \\
(38.2)\end{array}$ & Allen et al. (2008) \\
\hline & & $28.8-28.9$ & $<13$ & $<38.3$ & Vargas-Yáñez et al. (2012) \\
\hline & & & $11.5-13.0$ & $37.7-38.3$ & Juza et al. (2013) \\
\hline LIW & $\begin{array}{l}80-740 \\
(402)\end{array}$ & $\begin{array}{l}28.72-29.1 \\
(29.06) \\
\end{array}$ & $\begin{array}{l}13.2-14.2 \\
(13.91)\end{array}$ & $\begin{array}{l}38.24-38.74 \\
(38.70)\end{array}$ & REP14-MED data \\
\hline saline & & & $\begin{array}{l}\text { (summer } \\
13.51)\end{array}$ & $\begin{array}{l}\text { (summer } \\
38.58)\end{array}$ & Sparnocchia et al. (1994) \\
\hline \multirow[t]{5}{*}{ Strait of Sicily } & $200-800$ & & & $38.45-38.75$ & La Violette (1994) \\
\hline & $(300-500)$ & & $(13.2-14.0)$ & $(38.5-38.7)$ & Benzohra and Millot (1995) \\
\hline & $300-800$ & & $13.6-14.0$ & $38.64-38.70$ & Sorgente et al. (2003) \\
\hline & $300-400$ & & $13.2-14.0$ & $38.5-38.7$ & $\begin{array}{l}\text { Juza et al. (2013); } \\
\text { Juza et al. (2015) }\end{array}$ \\
\hline & $200-500$ & $29.03-29.10$ & & $(38.68-38.70)$ & Bosse et al. (2015) \\
\hline $\begin{array}{l}\text { WMDW } \\
\sigma_{\Theta} \text { changes small, }\end{array}$ & $\begin{array}{l}\text { upper } 540-1500 \\
\text { lower } 1500-2300\end{array}$ & $\begin{array}{l}29.10-29.11 \\
29.11-29.117\end{array}$ & $\begin{array}{l}12.91-13.70 \\
12.91-12.90\end{array}$ & $\begin{array}{l}38.48-38.68 \\
38.48-38.485 \\
\end{array}$ & REP14-MED data \\
\hline monotonic decrease & $800-3000$ & & $12.75-12.90$ & $38.4-38.48$ & La Violette (1994) \\
\hline \multirow[t]{2}{*}{ of $\Theta$ and $S$} & $>600$ & & $12.75-12.90$ & $38.42-38.47$ & Benzohra and Millot (1995) \\
\hline & & & $12.8-12.9$ & 38.48 & Testor and Gascard (2005) \\
\hline winter formation in & $>2000$ & 29.1 & $\leq 12.83$ in 2004 & $\leq 38.45$ in 2004 & Schroeder et al. (2008) \\
\hline NW Mediterranean & $>1000$ & 29.1 & $12.85-12.89$ & $38.48-38.50$ & Bosse et al. (2015) \\
\hline BW & $>2300$ & $\begin{array}{l}>29.118 \\
\text { (increase 0.005) }\end{array}$ & $\begin{array}{l}>12.91 \\
\text { (increase 0.01) }\end{array}$ & $\begin{array}{l}>38.49 \\
\text { (increase 0.01) }\end{array}$ & REP14-MED data \\
\hline increase of $\Theta, S, \sigma_{\Theta}$ & $>3000$ & & & & La Violette (1994) \\
\hline near bottom & $>2000$ & & 12.85 in 2005 & 38.46 in 2005 & Schroeder et al. (2008) \\
\hline same origin as & $>2000$ & in 2006 & $\begin{array}{l}12.85-12.88 \\
\text { in } 2006\end{array}$ & $38.455-38.47$ & Schroeder et al. (2008) \\
\hline $\begin{array}{l}\text { WMDW, developed } \\
\text { after WMT }\end{array}$ & 1900 & $\begin{array}{l}>29.11 \text { in } 2010 \\
29.119\end{array}$ & 12.90 in 2013 & 38.485 in 2013 & $\begin{array}{l}\text { Schroeder et al. (2016) } \\
\text { Schroeder et al. (2016) }\end{array}$ \\
\hline
\end{tabular}



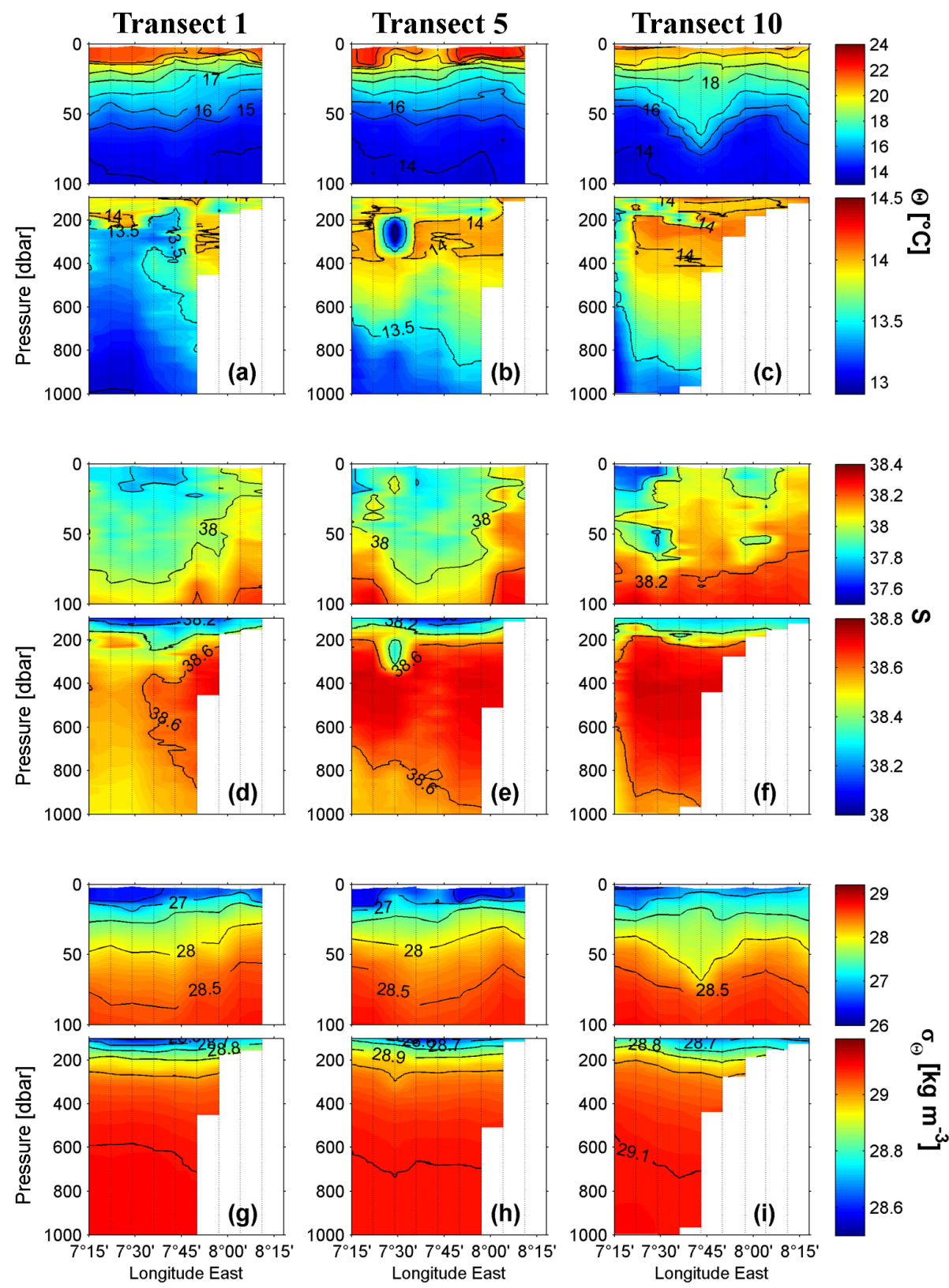

Figure 5. Potential temperature $(\Theta)$, salinity $(S)$, and potential density anomaly $\left(\sigma_{\Theta}\right)$ along the zonal (a, d, g) transect $1\left(40^{\circ} 12^{\prime} \mathrm{N}\right),(\mathbf{b}, \mathbf{e}$, h) transect $5\left(39^{\circ} 48^{\prime} \mathrm{N}\right)$, and $(\mathbf{c}, \mathbf{f}, \mathbf{i})$ transect $10\left(39^{\circ} 18^{\prime} \mathrm{N}\right)$ in the upper 100 and $1000 \mathrm{dbar}$ based on Planet CTD casts (dotted lines) given in Fig. 1.

two anticyclonic eddies in the Sardinian Sea (Sorgente et al., 2003).

Within the MAW, an intra-pycnocline anticyclonic eddy with a diameter of about $50 \mathrm{~km}$ was observed in the southern part of the domain, around $39^{\circ} 20^{\prime} \mathrm{N}$ and $7^{\circ} 43^{\prime} \mathrm{E}$ (Fig. 7). It was also apparent in transect 10, where the distance between the 27.5 and $28 \mathrm{~kg} \mathrm{~m}^{-3}$ isopycnals strongly increased (Fig. 5c, f, i). The presence of the eddy led to significantly modified local water properties, with strongest effects around 50 dbar (Russo et al., 2015; Borrione et al., 2015). Salinities measured within the eddy were close to 38.2 , and thus higher than those in the surrounding waters, in particular those to the west, where salinity ranged between 37.7 and 37.9 (Fig. 7). In the same area, just west of this eddy, where the low salinities were observed, the unusually low saline water mass described above, with salinities of less than 37.2, appeared at the surface at the end of the experiment. 

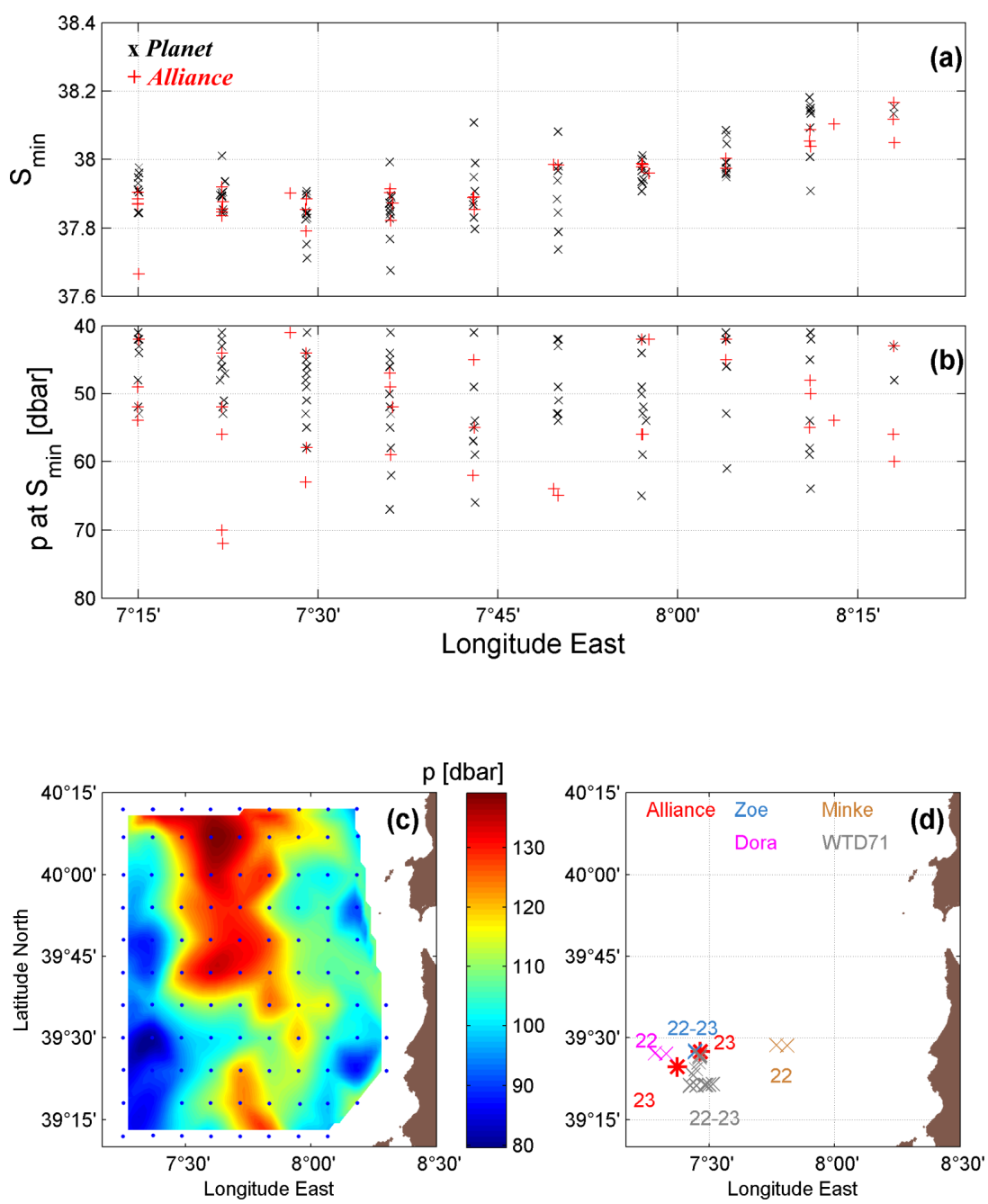

Figure 6. Characteristics of MAW, (a) salinity minimum $\left(S_{\min }\right)$ within 40 to 80 dbar of all Planet $(\mathrm{x})$ and Alliance (+) CTD casts, (b) corresponding pressure $(p)$ levels of $S_{\min }$, (c) pressure level of lower boundary of MAW $\left(\sigma_{\Theta}=28.72 \mathrm{~kg} \mathrm{~m}^{-3}\right)$ based on Planet CTD casts, and (d) positions (symbols) and June dates (numbers) of all CTD and glider profiles with measurements of unusually low saline surface water ( $S<37.32$ within 0 to $50 \mathrm{dbar})$.

\subsection{WIW/TML}

During REP14-MED, WIW was not observed as a continuous layer, but was confined to an anticyclonic WIW eddy detected by various platforms between 170 and $400 \mathrm{dbar}$ (Russo et al., 2015). It had a diameter of about $11 \mathrm{~km}$. Zonal transect 5 crossed the centre of this eddy (Fig. 5b, e, h). Several repeat CTD stations showed that the eddy moved northward during the experiment with a mean velocity of about $0.014 \mathrm{~m} \mathrm{~s}^{-1}$. The observed core values of the eddy (Table 2) were in agreement with previous observations of WIW in the northern WMED (Vargas-Yáñez et al., 2012; Juza et al., 2013), the Alboran Sea (Allen et al., 2008), and the Algerian Basin (Benzohra and Millot, 1995) (Table 2), but to our knowledge no WIW eddy with such low temperatures and salinities has been documented in the Sardinian Sea in the past.

A relatively cold $\left(<13.3^{\circ} \mathrm{C}\right)$ and fresh $(<38.3)$ water mass with core densities between 28.86 and $28.89 \mathrm{~kg} \mathrm{~m}^{-3}$ was detected between 120 and $270 \mathrm{dbar}$ in the southwestern part of the trial area (Fig. 8). To distinguish this water mass from the WIW transported by the eddy, it is called TML (Allen et al., 2008), though it was strongly influenced by WIW. Since the observed TML was warmer and less dense than the WIW eddy, it is likely that the two water masses have a different history, having formed at different times. Several patches of TML water with slightly higher potential temperatures were observed during the MedGOOS experiments all over the Sardinian Sea (Sorgente et al., 2003; Ribotti et al., 2004). 


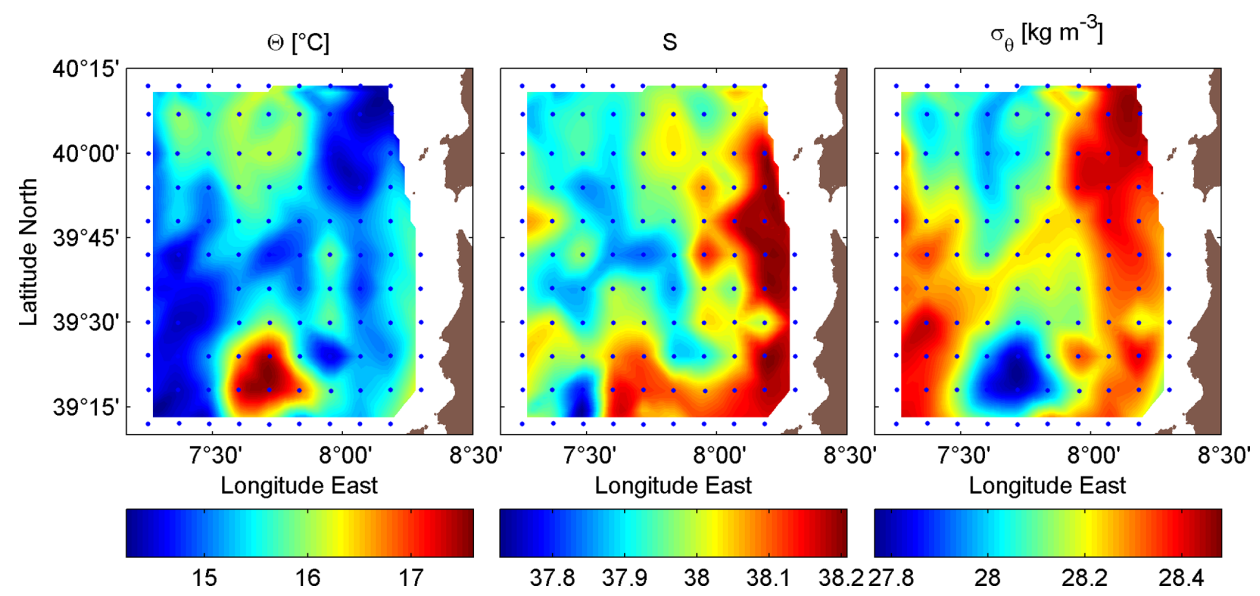

Figure 7. Potential temperature $(\Theta)$, salinity $(S)$, and potential density anomaly $\left(\sigma_{\Theta}\right)$ distribution at the pressure level of $50 \mathrm{dbar}$ based on CTD casts (blue dots) obtained by Planet from 8 to 18 June.

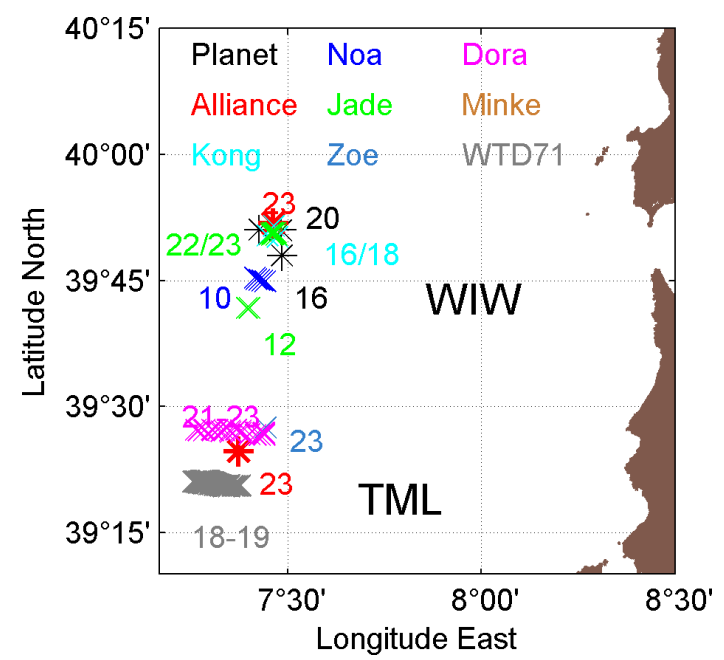

Figure 8. Positions (symbols) and June dates (numbers) of all CTD and glider profiles with WIW and TML observations, respectively ( $T<13.3^{\circ} \mathrm{C}$ and $S<38.33$ between 100 and 350 dbar).

Like the unusually low saline surface water, the TML entered the domain from the south and moved northward as indicated by the detection times (Fig. 8). It was not observed in the CTD measurements of Planet, which were obtained in the same area, but some time earlier before the first TML recording on the 18 June. Although TML and the unusually low surface salinities were detected in the same area at the end of the trial period, they did not always appear simultaneously as indicated by the WTD71 glider measurements. While the TML was already observed for the first time on 18 June (Fig. 8) the unusually low surface salinities were recorded some time later on 22 June (Fig. 6d).

\subsection{LIW}

The strong increase in salinity observed below $\sigma_{\Theta}=$ $28.72 \mathrm{~kg} \mathrm{~m}^{-3}$ indicated the presence of the LIW layer (Fig. 4) with core characteristics given in Table 2. Like MAW, LIW exhibited slightly higher salinity values compared to the historical data in the Sardinian Sea (Sparnocchia et al., 1994), likely due to the transfer of the EMT signal to the WMED (Roether et al., 2014).

East of $7^{\circ} 47^{\prime} \mathrm{E}$, the LIW core salinity of 38.71 showed only small changes, while farther offshore it varied between 38.55 and 38.74 due to relatively low values in the northeast (Fig. 9a and b). In contrast to earlier investigations, where LIW was attached closely to the Sardinian shelf break east of the $2000 \mathrm{~m}$ isobath (Puillat et al., 2003; Sorgente et al., 2003), during REP14-MED it covered the whole trial area west of the shelf. Only north of $40^{\circ} \mathrm{N}$ the LIW core was tied to the continental slope (Fig. 9d). However, the thickness of the LIW layer decreased towards the west to less than $500 \mathrm{~m}$ due to the rise of the isopycnals (Fig. 5g, h, i). For this study, the lower boundary of LIW was set to the potential density anomaly of $\sigma_{\Theta}=29.1 \mathrm{~kg} \mathrm{~m}^{-3}$, which corresponded to a pressure level between 540 and $740 \mathrm{dbar}$ (Fig. 9c). Deeper than this, the vertical increase in $\sigma_{\Theta}$ was strongly reduced (Fig. 2).

\subsection{WMDW}

The REP14-MED data set showed that the WMDW was separated into an upper and lower part (Fig. 4). The upper part was strongly influenced by the overlying LIW. The potential temperature and salinity decreased with depth from 13.70 to $12.91{ }^{\circ} \mathrm{C}$, and from 38.68 to 38.48 , respectively, while $\sigma_{\Theta}$ slightly increased from 29.10 to $29.11 \mathrm{~kg} \mathrm{~m}^{-3}$ (Fig. 2). Changes in the lower part, found below approximately $1500 \mathrm{~m}$, were very small. The potential temperature decreased and salinity increased only slightly by about 

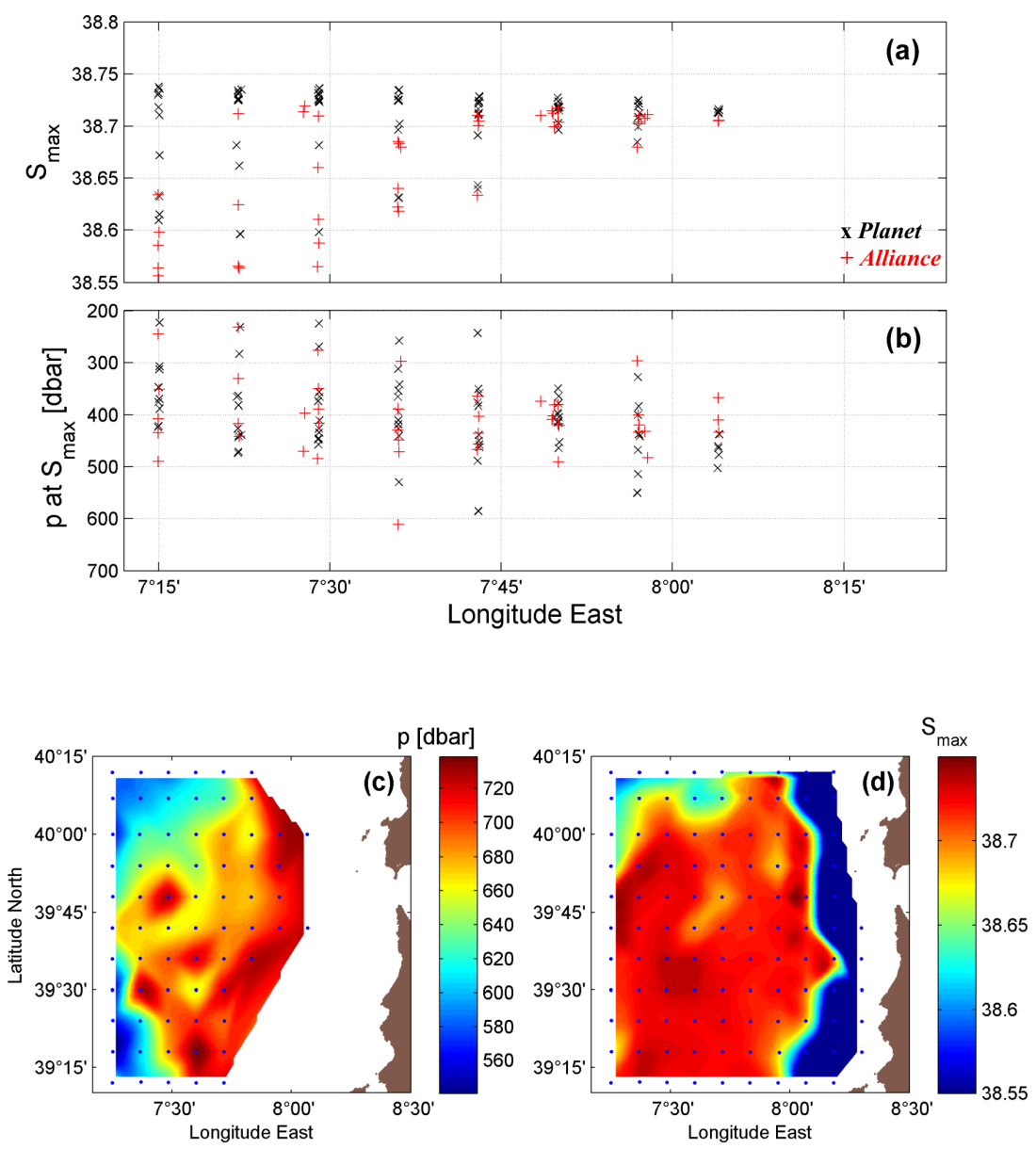

Figure 9. Characteristics of LIW, (a) salinity maximum $\left(S_{\max }\right)$ of at least 400 dbar deep CTD casts of Planet $(\mathrm{x})$ and Alliance $(+)$, (b) corresponding pressure level of $S_{\max }$, (c) pressure level of lower boundary of LIW $\left(\sigma_{\Theta}=29.1 \mathrm{~kg} \mathrm{~m}^{-3}\right.$ ) based on Planet CTD casts (blue dots), and (d) maximum salinity $\left(S_{\max }\right)>38.55$ based on Planet CTD casts (blue dots).
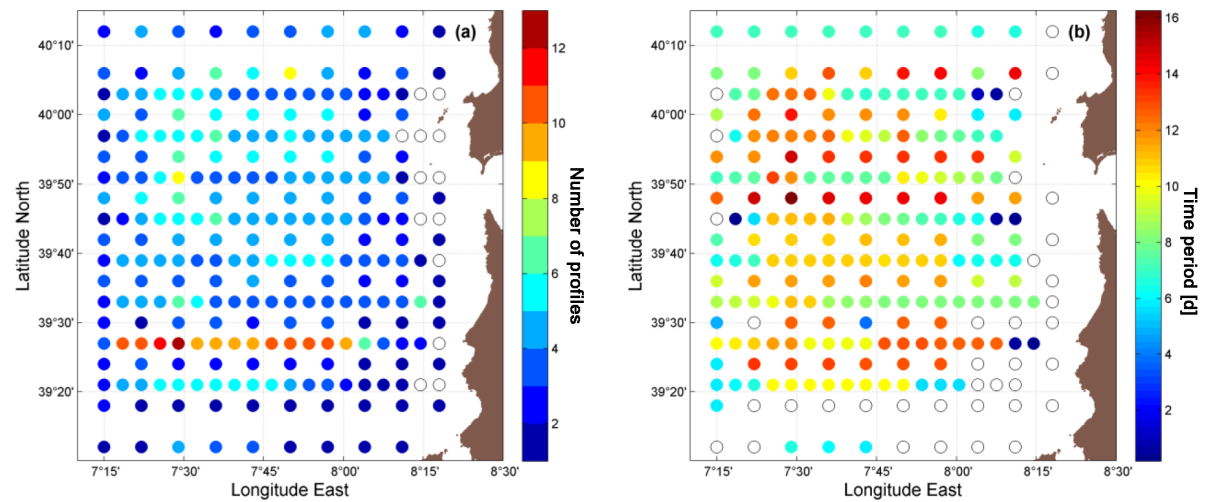

Figure 10. (a) Number of profiles gathered for each grid station (stations with no assigned profiles in white), and (b) time period in days between the first and last profile assigned to each grid station (stations with only one profile in white).

$0.01^{\circ} \mathrm{C}$ and 0.005 , respectively. These low values of about $12.90^{\circ} \mathrm{C}$ and 38.48 were in agreement with WMDW specifications given in the literature (La Violette, 1994; Benzohra and Millot, 1995; Testor and Gascard, 2005). A further in- crease in potential temperature and salinity below $2300 \mathrm{dbar}$ indicated the occurrence of BW. 


\subsection{BW}

BW was observed at the deep CTD stations on the western side of the domain. Below $2300 \mathrm{dbar}$, the WMDW showed an increase in potential temperature and salinity of about $0.01{ }^{\circ} \mathrm{C}$ and 0.01 , respectively, with a corresponding increase in $\sigma_{\Theta}$ of approximately $0.005 \mathrm{~kg} \mathrm{~m}^{-3}$ (Fig. 4). The increase started at potential temperatures and salinities of $12.91{ }^{\circ} \mathrm{C}$ and 38.49 , respectively. These values were even higher than those observed in previous investigations (Table 2), which detected a continuous increase in potential temperature, salinity, and layer thickness starting in winter 2004/2005 (Schroeder et al., 2008, 2016; Borghini et al., 2014).

\section{Short-term variability}

Due to various repetitions of CTD casts at fixed positions, the REP14-MED data set is perfectly suited for studying shortterm variability. Since most CTD casts covered only the upper water column, the variability estimations were restricted to MAW and LIW. Therefore, the differences between the CTD sensors were not considered. They were negligible with respect to the natural variability of the system.

In order to study variability of water mass characteristics in the region, a grid of stations was designed and for each grid point all profiles obtained from various instruments in close vicinity were gathered to investigate short-term temporal changes at a fixed location. The grid consisted of 259 stations, 107 of them almost matched the positions of the CTD stations which were $6 \mathrm{nmi}$ apart (Fig. 1). The other 152 stations were located along the glider tracks between $39^{\circ} 21^{\prime} \mathrm{N}$ and $40^{\circ} 3^{\prime} \mathrm{N}$ and between $7^{\circ} 15^{\prime} \mathrm{E}$ and $8^{\circ} 18^{\prime} \mathrm{E}$ with a distance of $3 \mathrm{nmi}$ in the east-west and $6 \mathrm{nmi}$ in the north-south directions. The glider as well as the ScanFish data were split into separate, alternating dive and climb profiles. For each profile, a geographical position was determined by calculating the mean position during the respective dive and climb period. All CTD, UCTD, CTD chain and ScanFish profiles within 2 nmi of a grid station were collected. The glider profiles within a zonal and meridional distance of 1 and $2 \mathrm{nmi}$, respectively, from a grid station were assigned to this position. All CTD chain, ScanFish, and glider profiles recorded in quick succession and allocated to the same grid station were replaced by the corresponding mean profiles. Between 0 and 13 profiles were allocated to each of the 259 grid stations (Fig. 10a). No profile was assigned to the 13 grid stations which were located at the eastern edge of the glider tracks. At 37 grid stations, only one profile was collected and 113 grid stations had 4 or more profiles assigned. The grid stations with more than one profile covered time periods between the first and last profile of 0.18 to 16.26 days (Fig. 10b). The short time periods were recorded at grid stations close to the turning points of the glider tracks. Time periods of 8 days and more were allocated to 139 grid stations.

To eliminate variations resulting from internal waves, temperature and salinity profiles were interpolated on $\sigma_{\Theta}$ levels with a step size of $0.02 \mathrm{~kg} \mathrm{~m}^{-3}$, which was above the observed accuracy. At the $\sigma_{\Theta}$ levels of the cores of MAW and LIW, mean temporal values of potential temperature and salinity as well as corresponding standard deviations and temporal gradients based on a linear least square fit were calculated (Fig. 11). The same calculations were carried out for the mean potential temperature and salinity values within the $\sigma_{\Theta}$ ranges of MAW and LIW (not shown). Both calculations showed very similar spatial distributions. Within MAW (Fig. 11, left panel), the highest salinities were observed close to the shore and in the anticyclonic eddy observed in the southern part of the trial area. The strongest variability occurred in close proximity to this eddy, as well as in the southwestern part of the domain, where a mean temporal decrease in salinity was observed. This was the area where unusually low saline water entered the region at the surface towards the end of the experiment. Farther north, the salinity variability was low. Occasional temporal increases in salinity were observed at those stations, where the corresponding time periods of the assigned profiles were short (Fig. 10b). The LIW core covered most of the trial area west of the shelf (Fig. 11, right panel). Less saline water was observed only in the northwestern part of the area, separated by a frontal region. The highest variability occurred at this front, with a temporal increase in salinity observed. A comparison between the CTD measurements of Alliance and Planet separated by about 8 days confirmed a northward movement of the front during the experiment. Temporal variability and gradients were comparatively low in all other regions. Corresponding calculations of variability and temporal gradients for potential temperature (not shown) yielded similar results.

\section{Circulation}

Underway current measurements were carried out with a vessel-mounted $75 \mathrm{kHz}$ ADCP on Alliance and a $150 \mathrm{kHz}$ ADCP on Planet. Due to severe functional problems all Planet ADCP data before 10 June were discarded. The later current measurements only had sufficient quality between 100 and $150 \mathrm{~m}$. There, they agreed well with the simultaneously recorded ADCP data of Alliance (Knoll et al., 2015b). Three periods of continuous current measurements at $125 \mathrm{~m}$ are presented in Fig. 12. Northward currents were mainly observed offshore, while a southward flow often occurred over the continental slope. At the end of the experiment, the ADCP measurements at $125 \mathrm{~m}$ depth showed southward currents in the southwest of the domain (Fig. 12c). The geographical position, depth, and time of these southward currents coincided with the TML water mass that appeared in this region. Although in general, the TML water moved 

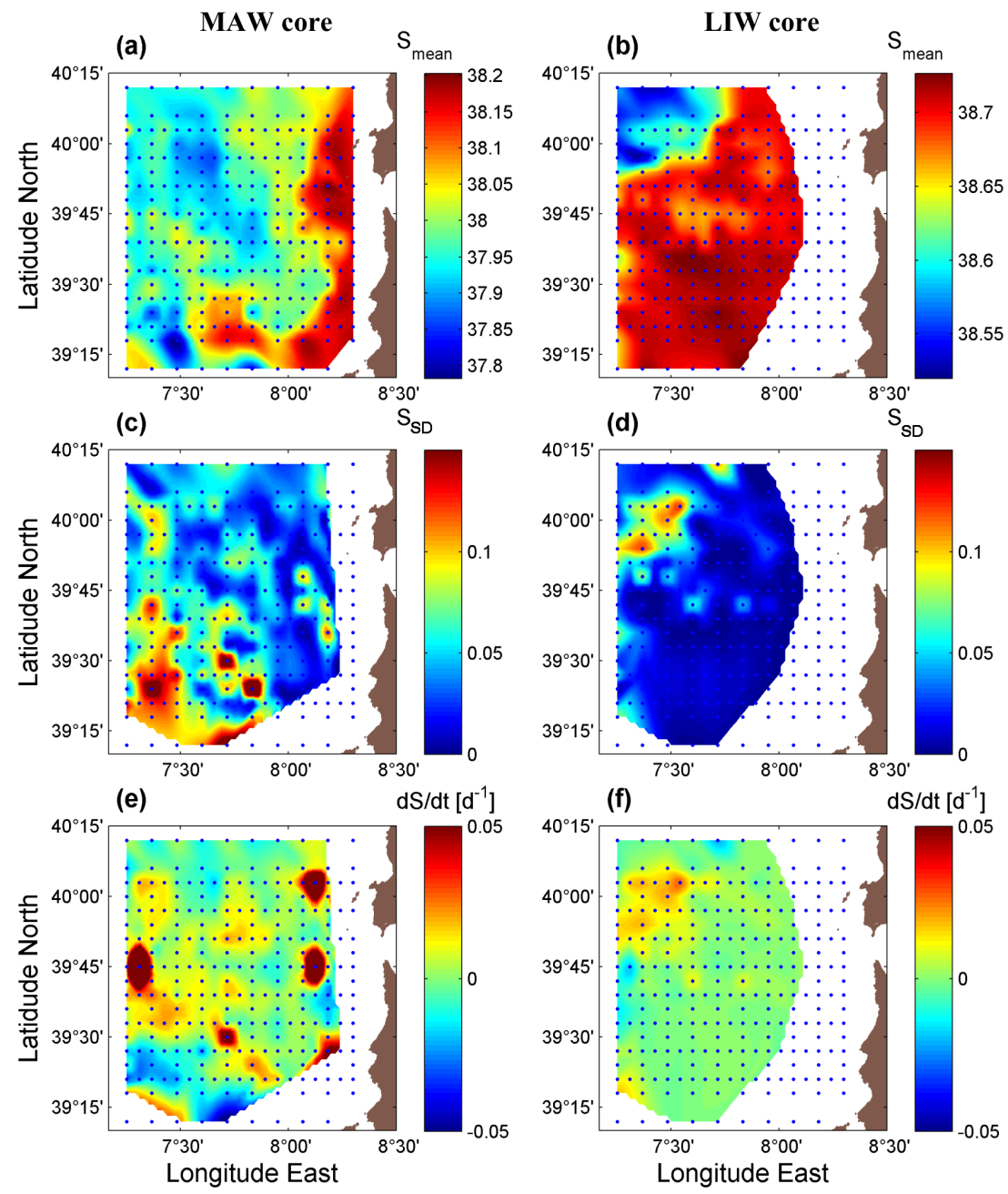

Figure 11. Mean salinity $\left(S_{\text {mean }}\right)$, standard deviation $\left(S_{\mathrm{SD}}\right)$, and linear temporal change in salinity per day $\left(\mathrm{d} S / \mathrm{d} t\left(\mathrm{~d}^{-1}\right)\right)$ in the cores of $(\mathbf{a}$, c, e) MAW $\left(\sigma_{\Theta}=28.2 \mathrm{~kg} \mathrm{~m}^{-3}\right)$ and $(\mathbf{b}, \mathbf{d}, \mathbf{f}) \operatorname{LIW}\left(\sigma_{\Theta}=29.06 \mathrm{~kg} \mathrm{~m}^{-3}\right)$ based on all collected data of the station grid (blue dots).

northward, this water mass may have been embedded in an anticyclonic eddy, with southward currents at its eastern edge. The anticyclonic eddy observed in the southern part of the trial area was evident in the upper ADCP measurements of Alliance (Russo et al., 2015; Borrione et al., 2015). The characteristics of this eddy (Fig. 7) were different from those expected in an AE with low salinities in the centre, or in a newly generated SE, since the eddy was limited to the upper $100 \mathrm{~m}$. The origin of this eddy should be further investigated. Like during the MedGOOS 3 observations (Ribotti et al., 2004), there was no clear indication of an AE or SE in the REP14-MED data set. The anticyclonic movement of the WIW eddy was observed in the vessel-mounted ADCP measurements of Alliance (Russo et al., 2015). The general northward movement of this eddy, as well as of the TML water observed further south (Fig. 8), matched the northward currents recorded offshore by the ADCPs (Fig. 12). The path and history of the observed WIW eddy, as well as of the TML water, should be explored in more detail.
Geostrophic currents and transports were calculated based on the CTD transects obtained by Alliance and Planet for the water masses of MAW $\left(\sigma_{\Theta} \leq 28.72 \mathrm{~kg} \mathrm{~m}^{-3}\right)$ and LIW $\left(28.72<\sigma_{\Theta} /\left(\mathrm{kg} \mathrm{m}^{-3}\right) \leq 29.1\right)$ (Fig. 13). A level of no motion (LNM) was assumed at $1000 \mathrm{dbar}$, which was within the upper WMDW and the maximum depth level of most of the CTD profiles. In shallower areas, the reference layer was set to the deepest value close to the bottom. For comparison, the LNM was also set to the isopycnal surface of $\sigma_{\Theta}=29.1 \mathrm{~kg} \mathrm{~m}^{-3}$, the boundary between LIW and WMDW (not shown). The geostrophic transports calculated with the different LNMs were similar, and the largest differences occurred within the meridional transports of LIW at the western boundary of the domain. Due to the rise of the $\sigma_{\Theta}=29.1 \mathrm{~kg} \mathrm{~m}^{-3}$ isopycnal (Fig. 9c), those transports were slightly smaller compared to the ones calculated with a LNM at $1000 \mathrm{dbar}$.

Within MAW, the meridional transports on the western side of the trial area, as well as over the Sardinian shelf, 

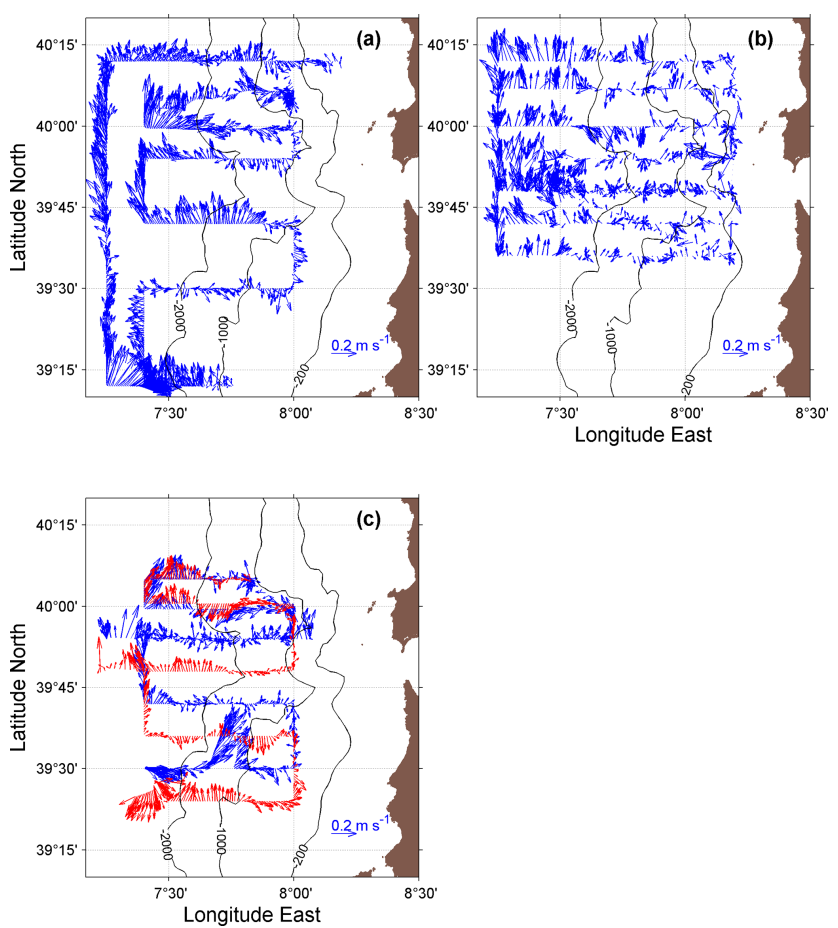

Figure 12. ADCP current vectors of Alliance (red) and Planet (blue) at $125 \mathrm{~m}$ depth averaged over $300 \mathrm{~s}$ for the time periods (a) 11 to 16 June, first CTD-chain tow; (b) 16 to 20 June, northern CTDtransects; and (c) 21 to 23 June, second CTD-chain/ScanFish tow, including the isobaths at 200, 1000, and $2000 \mathrm{~m}$ depth.

headed north, while over the continental slope mainly southward transports were observed (Fig. 13a, c). This matched the vessel-mounted ADCP measurements. The southward transport across each transect was about $-0.15 \mathrm{~Sv}$. The western extent of this southward flow reached areas with bottom depths of more than $2000 \mathrm{~m}$ in the northern CTD transects. In the south it was restricted to regions with bottom depths between 200 and $1000 \mathrm{~m}$. This southward flow resembled the WSC described by Olita et al. (2013), and the northward current in the west could be part of the Algerian Gyre (Testor and Gascard, 2005). The mean net transports across the zonal transects were mainly heading towards the north. They decreased from $0.38 \mathrm{~Sv}$ in the south to almost zero across the northern four transects. Measurements along the meridional transects were not synoptic, because the ship's route was mostly in the east-west direction, following the zonal transects shown in Fig. 1. Nevertheless, transport estimates were also calculated along meridional transects, as they could give additional insights into the MAW and LIW transports in the region. The zonal transports (Fig. 13e) showed mean westward transports around $-0.2 \mathrm{~Sv}$ west of $7^{\circ} 30^{\prime} \mathrm{E}$ and almost zero net transport in the eastern part of the trial area. The strong east- and westward transports in the southern domain at about $39^{\circ} 21^{\prime} \mathrm{N}$ and $30^{\circ} 15^{\prime} \mathrm{N}$, respectively, as well as the nearby north- and southward cur-
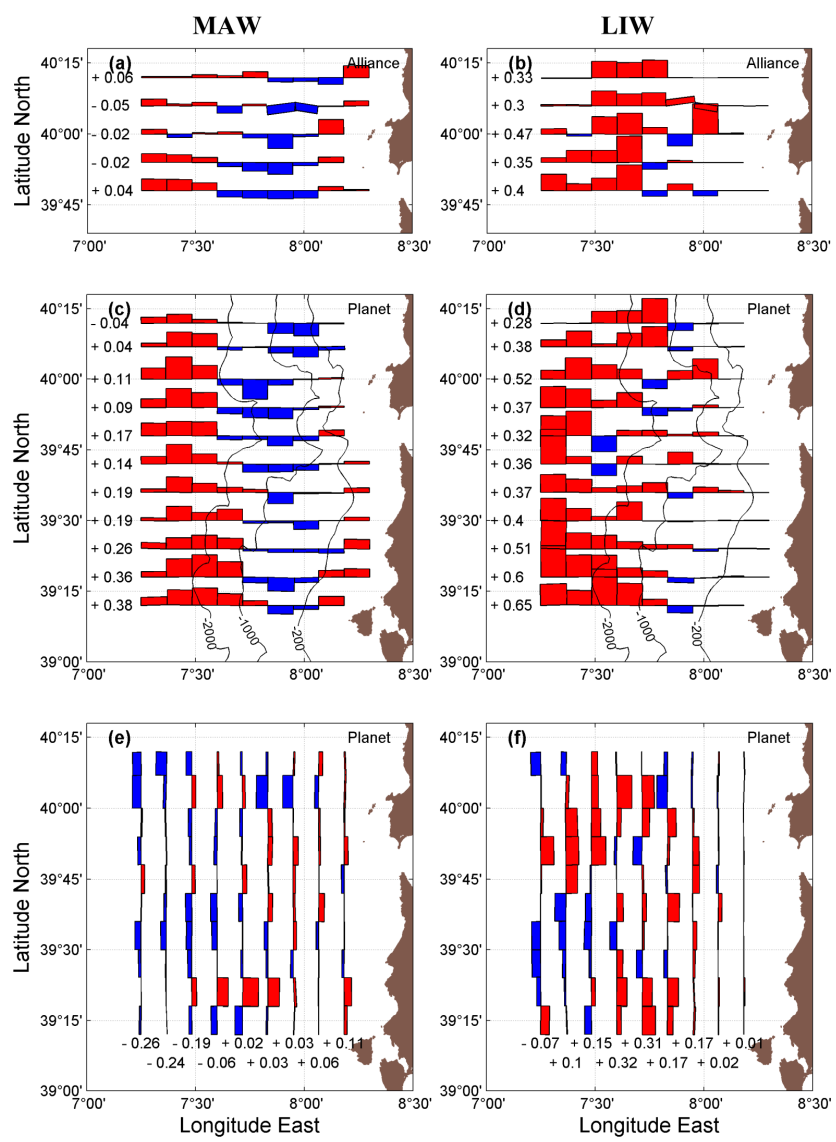

Figure 13. Geostrophic transports (Sv) calculated with a level of no motion (LNM) at $1000 \mathrm{dbar}$ and bottom, respectively, along the CTD transects of $(\mathbf{a}, \mathbf{b})$ Alliance and $(\mathbf{c}, \mathbf{d}, \mathbf{e}, \mathbf{f})$ Planet within the water masses (a, c, e) MAW and (b, d, f) LIW. The net transports are noted beside each transect. Plots of the meridional transports observed by Planet additionally show the isobaths at 200, 1000, and $2000 \mathrm{~m}$ depth.

rents, related well with the anticyclonic eddy described earlier (Russo et al., 2015; Borrione et al., 2015).

Within the LIW layer, northward transports prevailed over the whole trial area (Fig. 13b and d). Locally observed southward transports did not present a continuous flow, but in conjunction with the zonal transports probably indicated anticyclonic eddies in this layer (e.g. the southern and the WIW eddy). The transport rates over the shelf were negligible, since there the LIW covered only a small part of the water column, and the LNM was set to the bottom. Like in the MAW, the strongest transports to the north in the LIW occurred offshore. Only for the northernmost transects, the maximum northward flow took place over the continental slope. This fitted to the hydrographic distribution of LIW described earlier. The net northward transport of about $0.6 \mathrm{~Sv}$ across the southern transect declined to $0.3 \mathrm{~Sv}$ across the northern one (Fig. 13). 


\section{Summary and conclusions}

Since the hydrographic survey was based upon different CTD instruments, a sensor comparison was initially carried out. Because $\sigma_{\Theta}$ in the WMDW was nearly constant, small but nevertheless significant differences could be detected. Despite careful calibrations of the various sensors before the cruise, small but systematic differences in $\sigma_{\Theta}$ of about $\pm 0.01 \mathrm{~kg} \mathrm{~m}^{-3}$ were observed between some instruments, which was slightly above the expected nominal accuracies. Looking at profiles deeper than $2000 \mathrm{dbar}$, we identified conductivity as the cause of the differences between the Sea-Bird CTD sensors of Planet and Alliance. Systematic differences between the other deep profiling instruments (ARGO float, Seagliders, and Slocum gliders) appeared in the $\sigma_{\Theta}$ field, but the cause of this could not be identified. In the upper ocean, the differences between the sensor platforms were negligible compared to the natural variability. However, for studying density variations at greater depth, the shifts between the different sensors have to be taken into account. When planning to use different instruments in future studies to investigate small variations, it is important to pay attention to possible significant sensor discrepancies.

The characteristics of the different water masses observed during REP14-MED were presented and compared with previous results in the area. The most interesting features within the MAW, with $\sigma_{\Theta}<28.72 \mathrm{~kg} \mathrm{~m}^{-3}$ and salinity minima of about 37.93 at $50 \mathrm{dbar}$, were a $50 \mathrm{~km}$ wide anticyclonic eddy of unknown origin in the southern part of the domain, the appearance of unusually low saline surface water entering the area from the south at the end of the experiment, and a zonal salinity gradient with highest salinity values on the shelf. This gradient seemed quite common, either due to coastal upwelling or salinity reduction offshore caused by AEs. Unlike many other observations in this area (Ribotti et al., 2004; Testor and Gascard, 2005), no AEs or SEs were observed. Overall, the salinity in MAW in the Sardinian Sea has increased compared to previous investigations (Sparnocchia et al., 1994; Sorgente et al., 2003).

Further below, WIW was observed in an anticyclonic eddy with potential temperature and salinity values below $12.9^{\circ} \mathrm{C}$ and 38.3, respectively, at $250 \mathrm{dbar}$. Several repeat CTD stations showed that the eddy moved northward during the experiment with a mean velocity of about $0.014 \mathrm{~m} \mathrm{~s}^{-1}$. No previous observation of a WIW eddy in the Sardinian Sea with such low temperatures and salinities has been documented in the past. Slightly warmer and shallower TML water coming from the south was only recorded at the end of the cruise. During the MedGOOS experiments, TML was observed all over the Sardinian Sea (Sorgente et al., 2003, Ribotti et al., 2004). The path and history of the observed WIW eddy, as well as of the TML water, should be explored in more detail.

The LIW layer located at potential density anomalies between $28.72<\sigma_{\Theta} /\left(\mathrm{kg} \mathrm{m}^{-3}\right)<29.10$ covered the whole trial area from the Sardinian coast to $7^{\circ} 15^{\prime} \mathrm{E}$, but the thickness of the layer decreased towards the west. The LIW vein was tied only to the continental slope north of $40^{\circ} \mathrm{N}$, as was observed for the whole area in previous measurements (Sorgente et al., 2003). The LIW core exhibited mean potential temperatures and salinities of $13.91^{\circ} \mathrm{C}$ and 38.70 , respectively. These values were higher than the historical data in the Sardinian Sea (Sparnocchia et al., 1994), likely due to the transfer of the EMT signal to the WMED (Roether et al., 2014).

The WMDW was divided into two parts, with larger vertical gradients in the upper water column and smaller variations in the lower water column (below $1500 \mathrm{dbar}$ ). The potential temperature and salinity values of the lower WMDW of $12.9^{\circ} \mathrm{C}$ and 38.38 , respectively, were in good agreement with earlier investigations (La Violette, 1994; Benzohra and Millot, 1995; Testor and Gascard, 2005). The rise in temperature and salinity in the BW due to the WMT was observed in the deep CTD profiles. The potential temperature and salinity values of greater than $12.91^{\circ} \mathrm{C}$ and greater than 38.49 , respectively, confirmed the continuous increase since winter 2004/2005 (Schroeder et al., 2008, 2016; Borghini et al., 2014). In general, the CTD measurements confirmed the steady increase in the heat and salt content in the different water masses of the WMED observed since the last decades. The data set might contribute to further investigations addressing the long-term evolution on hydrography in the WMED, where considerable changes occurred after the EMT and WMT.

Due to various repetitions of CTD casts at fixed positions, the data set was perfectly suited for studying short-term variability in the upper water column. In the MAW, the strongest variability was observed around the southern eddy, as well as in the southwestern part of the region, where unusually low saline surface water entered the area after 17 June. In the LIW, the highest variability occurred at the front in the northwest, moving northward over the course of the experiment.

The direct current measurements in the upper ocean obtained with vessel-mounted ADCPs reflected the occurrence of anticyclonic eddies (e.g. the southern and WIW eddy). Northward currents were mainly observed offshore, while a southward flow often occurred over the continental slope. The relatively calm wind conditions induced only very light upwelling, increasing the salinity on the shelf.

Geostrophic currents and transports were calculated across the CTD transects assuming a LNM at $1000 \mathrm{dbar}$. In general, the results matched the ADCP observations. Within the MAW, the meridional transports offshore and over the shelf headed north, while over the continental slope mainly southward transports of about $-0.15 \mathrm{~Sv}$ were observed, resembling the WSC described by Olita et al. (2013). The mean net transports across the zonal transects were mainly heading towards the north, decreasing from $0.38 \mathrm{~Sv}$ in the south to almost zero in the north. Within the LIW, northward transports of about $0.6 \mathrm{~Sv}$ in the south primarily occurred offshore, decreasing to $0.3 \mathrm{~Sv}$ in the north, where it was located over the slope, corresponding to the observed spreading of 
LIW. There was no continuous southward flow over the slope but occasional southward currents were probably often part of anticyclonic eddies in the LIW. The observed northward transport rates west of Sardinia were about half of the estimated 1 Sv LIW entering the WMED.

Data availability. All REP14-MED experimental data are available on the data server at the Centre for Maritime Research and Experimentation (CMRE). The data are NATO Unclassified and are available only for the partners of the experiment. However, interested institutions can sign up for partnership at any time. Requests may be directed to registry@cmre.nato.int.

Author contributions. MK was responsible for the collection and processing of CTD, CTD chain, UCTD, and ADCP data on Planet. IB and AR contributed to the analysis of the CTD, ScanFish, and ADCP data of Alliance and the CMRE Slocum gliders. AF processed the data of the WTD71 glider. The Seaglider data were processed by MH and BQ, supervised by JK. RO was the coordinator of the experiment and chief scientist on Alliance, while H-VF was chief scientist on Planet. MK prepared the manuscript with contributions of all co-authors.

Competing interests. The authors declare that they have no conflict of interest.

Special issue statement. This article is part of the special issue "REP14-MED: A Glider Fleet Experiment in a Limited Marine Area". It is not associated with a conference.

Acknowledgements. The authors want to thank all crew members of the research vessels Alliance and Planet for helping to collect such an extraordinary data set. Thanks go to all scientists and technicians involved in the field campaign and data processing. Special thanks go to Pierre-Marie Poulain for providing the ARGO float data, and to Karen Heywood, the principal investigator from UEA, and Gareth Lee, head of the UEA Glider Facility, for providing the Seagliders. Jan Kaiser, Karen Heywood, and Michael Hemming were supported by funding from the Defence Science and Technology Laboratory (DSTL, UK) in close co-operation with Direction générale de l'armement (DGA, France). CMRE activities, including Alliance, were supported by the NATO Allied Command Transformation (ACT) through project SAC000404.

Edited by: Giovanni Quattrocchi

Reviewed by: two anonymous referees

\section{References}

Allen, J. T., Painter, S. C., and Rixen, M.: Eddy transport of Western Mediterranean Intermediate Water to the Alboran Sea, J. Geophys. Res., 113, C04024, https://doi.org/10.1029/2007JC004649, 2008.

Benzohra, M. and Millot, C.: Characteristics and circulation of the surface and intermediate water masses off Algeria, Deep-Sea Res. Pt. I, 42, 10, 1803-1830, 1995.

Bethoux, J.-P.: Mean water fluxes across sections in the Mediterranean Sea, evaluated on the basis of water and salt budgets and of observed salinities, Oceanol. Ac., 3, 79-88, 1980.

Borghini, M., Bryden, H., Schroeder, K., Sparnocchia, S., and Vetrano, A.: The Mediterranean is becoming saltier, Ocean Sci., 10, 693-700, https://doi.org/10.5194/os-10-693-2014, 2014.

Borrione, I., Russo, A., Fiekas, H.-V., Heywood, K., Knoll, M., and Onken, R.: Prominent sub-mesoscale variability in the west Sardinian Sea as revealed by multi-platform sampling strategy, EGU General Assembly 2015, Vienna, Austria, 2015EGUA..17.1795B, 2015.

Bosse, A., Testor, P., Mortier, L., Prieur, L., Taillandier, V., d'Ortenzio, F., and Coppola, L.: Spreading of Levantine Intermediate Waters by submesoscale coherent vortices in the northwestern Mediterranean Sea as observed with gliders, J. Geophys. Res.-Oceans, 120, 1599-1622, https://doi.org/10.1002/2014JC010263, 2015.

Bouzinac, C., Font, J., and Millot, C.: Hydrology and currents observed in the channel of Sardinia during the PRIMO-1 experiment from November 1993 to October 1994, J. Mar. Syst., 20, 333-355, 1999.

Fuda, J.-L., Millot, C., Taupier-Letage, I., Send, U., and Bocognano, J. M.: XBT monitoring of a meridian section across the Western Mediterranean Sea, Deep-Sea Res., 47, 2191-2218, 2000.

Juza, M., Renault, L., Ruiz, S., and Tintoré, J.: Origin and pathways of Winter Intermediate Water in the Northwestern Mediterranean Sea using observations and numerical simulation, J. Geophys. Res.-Oceans, 118, 6621-6633, https://doi.org/10.1002/2013JC009231, 2013.

Juza, M., Mourre, B., Lellouche, J.-M., Tonani, M., and Tintoré, J.: From basin to sub-basin scale assessment and intercomparison of numerical simulations in the Western Mediterranean Sea, J. Mar. Syst., 149, 36-49, 2015.

Knoll, M., Benecke, J., Russo, A., and Ampolo-Rella, M.: Comparison of CTD measurements obtained by NRV Alliance and RV Planet during REP14-MED, Technical Report WTD710083/2015 WB, 34 pp., 2015a.

Knoll, M., Benecke, J., and Borrione, I.: ADCP measurements obtained by RV Planet during REP14-MED, Technical Report WTD71-0094/2015 WB, 52 pp., 2015b.

Krahmann, G. and Schott, F.: Longterm increases in western Mediterranean salinities and temperatures: Anthropogenic and climate sources, Geophys. Res. Lett., 25, 4209-4212, 1998.

La Violette, P. E.: Overview of the Major Forcings and Water Masses of the Western Mediterranean Sea, Coastal and Estuarine Studies, Seasonal and Interannual Variability of the Western Mediterranean Sea, edited by: P. E. La Violette, American Geophysical Union, Washington, DC, 1994.

Millot, C.: Circulation in the Western Mediterranean Sea, J. Mar. Syst., 20, 423-442, 1999.

Millot, C. and Taupier-Letage, I.: Additional evidence of LIW entrainment across the Algerian subbasin by mesoscale eddies and not by a permanent westward flow, Prog. Oceanogr., 66, 231$250,2005$. 
Olita, A., Ribotti, A., Fazioli, L., Perilli, A., and Sorgente, R.: Surface circulation and upwelling in the Sardinia Sea: A numerical study, Cont. Shelf Res., 71, 95-108, https://doi.org/10.1016/j.csr.2013.10.011, 2013.

Olita, A., Iermano, I., Fazioli, L., Ribotti, A., Tedesco, C., Pessini, F., and Sorgente, R.: Impact of currents on surface flux computations and their feedback on dynamics at regional scales, Ocean Sci., 11, 657-666, https://doi.org/10.5194/os-11-6572015, 2015.

Onken, R., Fiekas, H.-V., Beguery, L., Borrione, I., Funk, A., Hemming, M., Heywood, K. J., Kaiser, J., Knoll, M., Poulain, P.-M., Queste, B., Russo, A., Shitashima, K., Siderius, M., and ThorpKüsel, E.: High-Resolution Observations in the Western Mediterranean Sea: The REP14-MED Experiment, Ocean Sci. Discuss., https://doi.org/10.5194/os-2016-82, in review, 2016.

Pinardi, N., Zavatarelli, M., Adani, M., Coppini, G., Fratianni, C., Oddo, P., Simoncelli, S., Tonani, M., Lyubartsev, V., Dobricic, S., and Bonaduce, A.: Mediterranean Sea large-scale low-frequency ocean variability and water mass formation rates from 1987 to 2007: A retrospective analysis, Prog. Oceanogr., 132, 318-332, https://doi.org/10.1016/j.pocean.2013.11.003, 2015.

Puillat, I., Millot, C., and Taupier-Letage, I.: Algerian Eddies lifetime can near 3 years, J. Mar. Syst., 31, 245-259, 2002.

Puillat, I., Sorgente, R., and Ribotti, A.: Circulation in the Sardinian Sea: A synergetic approach by in situ data, a three dimensional model and infrared imagery, Geophys. Res. Abst., 5, 13117, 2003.

Puillat, I., Sorgente, R., Ribotti, A., Natale, S., and Echevin, V.: Westward branching of LIW induced by Algerian anticyclonic eddies close to the Sardinian slope, Chem. Ecol., 22, 293-305, https://doi.org/10.1080/02757540600670760, 2006.

Ribotti, A., Puillat, I., Sorgent, R., and Natale, S.: Mesoscale circulation in the surface layer off the southern and western Sardinia Island in 2000-2002, Chem. Ecol., 20, 345-363, 2004.

Rixen, M., Beckers, J.-M., Levitus, S., Antonov, J., Boyer, T., Maillard, C., Fichaut, M., Balopoulus, E., Iona, S., Dooley, H., Garcia, M.-J., Manca, B., Giorgetti, A., Manzella, G., Mikhailov, N., Pinardi, N., and Zavatarelli, M.: The Western Mediterranean Deep Water: A proxy for climate change, Geophys. Res. Lett., 32, L12608, https://doi.org/10.1029/2005GL022702, 2005.

Roether, W., Klein, B., Manca, B. B., Theocharis, A., and Kioroglou, A.: Transient eastern Mediterranean deep waters in response to the massive dense-water output of the Aegean Sea in the 1990s, Prog. Ocean., 74, 540-571, https://doi.org/10.1016/j.pocean.2007.03.001, 2007.
Roether, W., Klein, B., and Hainbucher, D.: The Eastern Mediterranean Transient: Evidence for Similar Events Previously?, in: The Mediterranean Sea: Temporal Variability and Spatial Patterns, Geophysical Monograph 202. First Edition, edited by: Borzelli, G. L. E., Gačić, M., Lionello, P., and Malanotte-Rizzoli, P., (CAmerican Geophysical Union, John Wiley \& Sons, Inc, 2014.

Russo, A., Borrione, I., Falchetti, S., Knoll, M., Fiekas, H.-V., Heywood, K., Oddo, P., and Onken, R.: Intense mesoscale variability in the Sardinian Sea. EGU General Assembly 2015, Vienna, Austria, 2015EGUA..17.1745R, 2015.

Schott, F., Visbeck, M., Send, U., Fischer, J., Stramma, L., and Desaubies, Y.: Observations of deep convection in the Gulf of Lions, northern Mediterranean, during the winter of 1991/92, J. Phys. Ocean., 26, 505-524, 1996.

Schroeder, K., Ribotti, A., Borghini, M., Sorgente, R., Perilli, A., and Gasparini, G. P.: An extensive Mediterranean deep water renewal between 2004 and 2006, Geophys. Res. Lett., 35, L18605, https://doi.org/10.1029/2008GL035146, 2008.

Schroeder, K., Chiggiato, J., Bryden, H. L., Borghini, M., and Ben Ismail, S.: Abrupt climate shift in the Western Mediterranean Sea, Scientific Reports, 6, 23009, https://doi.org/10.1038/srep23009, 2016.

Sorgente, R., Ribotti, A., and Puillat, I.: Water masses and diagnostic circulation west of Sardinia from 23 March to 4 April 2001, Building the European Capacity in Operational Oceanography: Proceedings of the third international conference on EuroGOOS, edited by: Dahlin, H., Elsevier, 2003.

Sparnocchia, S., Manzella, G. M. R., and La Violette, P. E.: The Interannual and Seasonal Variability of the MAW and LIW Core Properties in the Western Mediterranean Sea, Coastal and Estuarine Studies, Seasonal and Interannual Variability of the Western Mediterranean Sea, edited by: La Violette, P. E., American Geophysical Union, Washington, DC, 1994.

Taupier-Letage, I., Puillat, I., Millot, C., and Raimbault, P.: Biological response to mesoscale eddies in the Algerian Basin, J. Geophys. Res., 108, 3245, https://doi.org/10.1029/1999JC000117, 2003.

Testor, P. and Gascard, J.-C.: Large scale flow separation and mesoscale eddy formation in the Algerian Basin, Prog. Oceanogr., 66, 211-230, 2005.

Vargas-Yáñez, M., Zunino, P., Schroeder, K., López-Jurado, J. L., Plaza, F., Serra, M., Castro, C., García-Martínez, M. C., Moya, F., and Salat, J.: Extreme Western Intermediate Water formation in winter 2010, J. Mar. Syst., 105-108, 52-59, 2012. 